\title{
Sedimentation process of ashfall during a Vulcanian eruption as revealed by high- temporal-resolution grain size analysis and high-speed camera imaging
}

\author{
T. Miwa ${ }^{1 *}$ (D, Y. Iriyama ${ }^{1}$, M. Nagai ${ }^{1}$ and F. Nanayama ${ }^{2}$
}

\begin{abstract}
We here examined the sedimentation process of falling ash particles during a short-lived Vulcanian eruption at Sakurajima volcano, Japan, using high-speed camera imaging of airborne ash particles, as well as grain size analyses of ash samples collected at high temporal resolution. Ashfalls from a sequence of two Vulcanian eruptions at 10:44 and 11:26 JST (Japan Standard Time) on 26 March 2016 were investigated. The field site for imaging and sampling was located approximately $3.5 \mathrm{~km}$ from the vent. The ash particles collected exhibit bimodal grain size distributions (GSDs). The median particle size of the main subpopulation decreased throughout the ashfall owing to sizedependent segregation of ash particles from a single source released from a constant height. The volume fraction of the subordinate subpopulation is interpreted to represent a component of ash aggregates and shows an increase in its volume fraction after the eruption onset. High-speed camera imaging reveals that the mean particle density decreased over time as the ashfall continued. These data suggest an increasing contribution of low-density aggregates during the course of the ashfall. The temporal changes in the density of airborne ash particles and in the GSD of ash samples demonstrate that the sedimentation process during a Vulcanian eruption at Sakurajima volcano is characterized by sedimentation of ash particles from transient eruption plumes at constant height, in which ash aggregation increases over time. Moreover, time series analysis of the ash falling rate shows that secondary thickening occurred during these Vulcanian eruptions and that this can be triggered by the settling of ash aggregates.
\end{abstract}

Keywords: Volcanic ash, Aggregation, High-speed camera imaging, High-resolution temporal sampling, Grain size distribution, Vulcanian eruption, Sakurajima volcano

\section{Introduction}

Explosive eruptions generate and disperse tephra that deposits around a volcano. The characteristics of these tephra deposits reflect their sedimentation process, which is controlled by eruptive style, wind conditions, and the aerodynamic properties of the particles (e.g., Iriyama et al. 2018; Koyaguchi and Ohno 2001a; Walker 1971; Wohletz et al. 1989). Many previous studies have investigated deposit characteristics to evaluate the sedimentation process for Plinian and sub-Plinian eruptions,

\footnotetext{
*Correspondence: miwao@bosai.go.jp

${ }^{1}$ National Research Institute for Earth Science and Disaster Resilience,

Tennodai 3-1, Tsukuba 305-0006, Japan

Full list of author information is available at the end of the article
}

whereas the number of studies that have examined sedimentation processes for Vulcanian eruption is still limited (e.g., Bonadonna et al. 2002; Eychenne et al. 2012; Miyabuchi et al. 2013). Vulcanian eruptions are commonly defined as short-lived explosive eruptions lasting from few seconds to few hours (Clarke 2013). These eruptions often occur intermittently during persistent volcanic activity (Clarke 2013; Hammer et al. 1999; Iguchi et al. 2013). Although the eruptive mass $\left(<0.1 \mathrm{~km}^{3}\right)$ and eruptive column height (typically $<10 \mathrm{~km}$ ) of single Vulcanian events are relatively small, a series of Vulcanian eruptions can produce thick, edifice-forming ash deposits (Andronico and Cioni 2002; Imura 1991, 1995). 
High-temporal resolution grain size analysis of tephra deposits can provide information on the process of sedimentation during Vulcanian eruptions. The tephra source during a Vulcanian eruption is considered a discrete "volcanic thermal" (Woods and Kienle 1994) which refers to instantaneous emission of batch of volcanic cloud or a ring vortex at the head of a transient plume (Chojnicki et al. 2014; Chojnicki et al. 2015a; Chojnicki et al. 2015b; Tournigand et al. 2017). We investigate tephra sedimentation by assessing temporal variations in the grain size distribution (GSD) of tephra, which reflects the sedimentation process (e.g., Iriyama et al. 2018; Koyaguchi and Ohno 2001b). The deposit from a single Vulcanian eruption is generally too thin to examine its temporal variations from the internal stratigraphy (Imura 1991, 1995; Miura et al. 2012; Miyabuchi et al. 2013). Therefore, high-temporal resolution sampling of falling ash is required to obtain the temporal variation in GSD during a Vulcanian eruption (Bagheri et al. 2016; Bonadonna et al. 2002). Bonadonna et al. (2002) sampled falling ash particles at $5 \mathrm{~min}$ intervals during a series of Vulcanian eruptions at Soufrière Hills Volcano, Montserrat, and found a progression from a unimodal to bimodal GSD in the ash samples. Previous studies, however, have not performed a detailed examination of a polymodal GSD during a Vulcanian eruption, including the use of deconvolution analysis to derive the origin of particle size subpopulations within a tephra deposit (Evans et al. 2009; Eychenne et al. 2012; Wohletz et al. 1989).

Ash aggregation alters the aerodynamic properties of tephra and affects the sedimentation process (e.g., Carey and Sigurdsson 1982; Costa et al. 2010). Ash aggregates from dry eruptions are generally fragile and are rarely preserved in the deposit after reaching the ground surface (Bonadonna et al. 2011; Gilbert et al. 1991; James et al. 2003; Sparks et al. 1997; Taddeucci et al. 2011). Therefore, in situ observation of falling particles is needed to quantify the properties (size, falling velocity, and density) of the aggregates (Bagheri et al. 2016; Taddeucci et al. 2011). For Vulcanian eruptions, Bagheri et al. (2016) described the temporal variation in ash aggregates at Sakurajima volcano, based on high-speed, high-resolution camera imaging. The effects of aggregation on the sedimentation process during a Vulcanian eruption are, however, still poorly constrained.

In this study, we investigated temporal variations in the sedimentation process of falling ash particles during a Vulcanian eruption at Sakurajima volcano, Japan. We conducted a detailed grain size analysis of ash samples collected at high temporal resolution and observed airborne ash particles using high-speed camera imaging. The combination of these analyses provides detailed insights into the sedimentation process of ash particles, including the effects of ash aggregation, during a shortlived Vulcanian eruption.

\section{Vulcanian activity at Sakurajima volcano}

Sakurajima volcano (Fig. 1a) is an active andesitic volcano located in southern Kyushu, Japan. Large-scale eruptions of Sakurajima have generated both tephra deposits and lava flows (Kobayashi et al. 2013). Recent Vulcanian activity at Sakurajima has been ongoing since 1955, and deposits have attained a maximum cumulative thickness of $120 \mathrm{~cm}$ at a site $2 \mathrm{~km}$ west from the vents since that time (Imura 1995). The main eruptive vent switched from the Minamidake summit crater to the Showa crater in 2006. The Showa crater is located on the southeastern edifice at an altitude of approximately 800 m.a.s.l. (Iguchi et al. 2010). The Japan Meteorological Agency (JMA) reported over 5500 explosions in the Showa crater from 2006 to 2017. The volumes of some of the individual Vulcanian eruptions are estimated to range from $5.9 \times 10^{-7}$ to $3.6 \times 10^{-6} \mathrm{~km}^{3}$ (Oishi et al. 2018). Their eruptive products are characterized by angular and dense clasts ranging in size from ash particles to volcanic bombs (Miwa et al. 2013).

\section{Methods/Experimental \\ Studied eruption}

We studied a sequence of Vulcanian eruptions from the Showa crater on 26 March 2016 (Fig. 1b). The first eruption occurred at 10:44 and was followed by a second eruption at 11:26 Japan Standard Time (JST). Figure 2 captures the development of the volcanic cloud during this sequence of Vulcanian eruptions. The first eruption comprised an instantaneous initial jet followed by an ash-rich mushroom cloud. The volcanic plume ascended vertically, reaching a maximum height of 3500 m.a.s.l. $180 \mathrm{~s}$ after the onset of the eruption (Report of eruptive activity at Sakurajima volcano published by Japan Meteorological Agency (JMA); https://www.jma-net.go.jp/ kagoshima/vol/data/skr_exp_2016.html). The second eruption generated a volcanic cloud consisting of an initial jet phase followed by a weak mushroom cloud. The maximum height of the volcanic cloud during the second eruption was recorded as 2900 m.a.s.l. $180 \mathrm{~s}$ after the start of the eruption (Report of eruptive activity at Sakurajima volcano published by JMA; https://www.jmanet.go.jp/kagoshima/vol/data/skr_exp_2016.html). Since the maximum height of the second eruption was smaller, thermal energy and the ash content should be smaller. The volcanic clouds from both the first and second eruptions were spread by westerly wind with a velocity of $\sim 10 \mathrm{~m} \mathrm{~s}^{-1}$ (Fig. 3) (Meteorological data set published by JMA; http://www.data.jma.go.jp/obd/stats/etrn/index. php). Pyroclastic density currents were not observed during the studied eruptions (Fig. 2). 


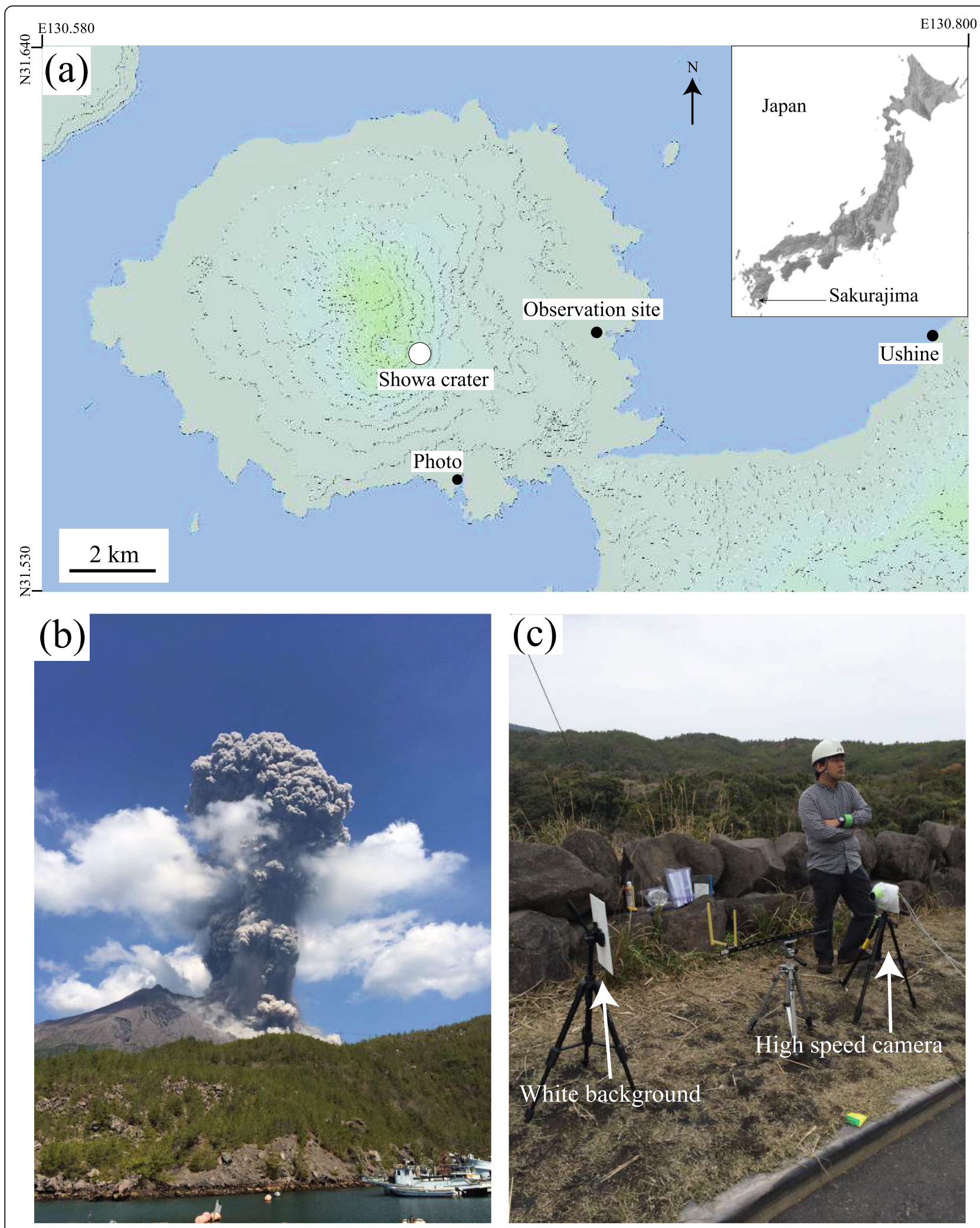

Fig. 1 (See legend on next page.) 
(See figure on previous page.)

Fig. 1 a Locations of Sakurajima volcano and the field observation site (N31.581622, E130.705992). The location map was based on the Digital Topographic Map published by the Geospatial Information Authority of Japan and processed using Kashmir software. Ushine indicates location of the time-lapse camera installed by JMA (see Fig. 2). b Photograph of the studied eruption, which started at 10:44 JST, 26 March 2016. View from the location of photo in this figure. The height of column in this photo is approximately $900 \mathrm{~m}$. c Field observation site and view of instrument setup
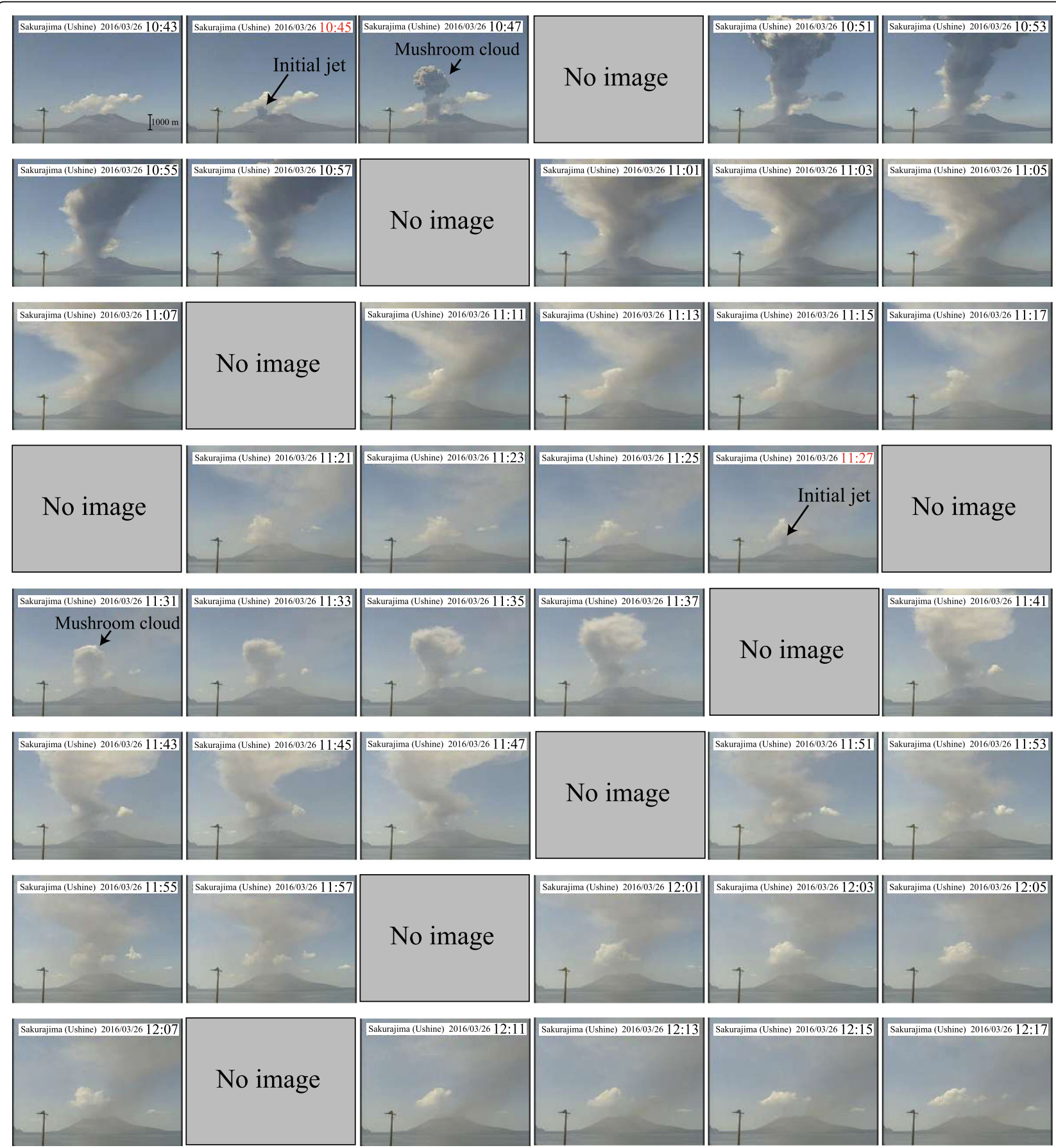

Fig. 2 Images obtained from the time-lapse camera installed by JMA in the Ushine area, which is located approximately $10 \mathrm{~km}$ east of the Showa crater (see Fig. 1). The images were taken at 10:43-12:17 JST, 26 March 2016, with a frequency of one image every 2 min 

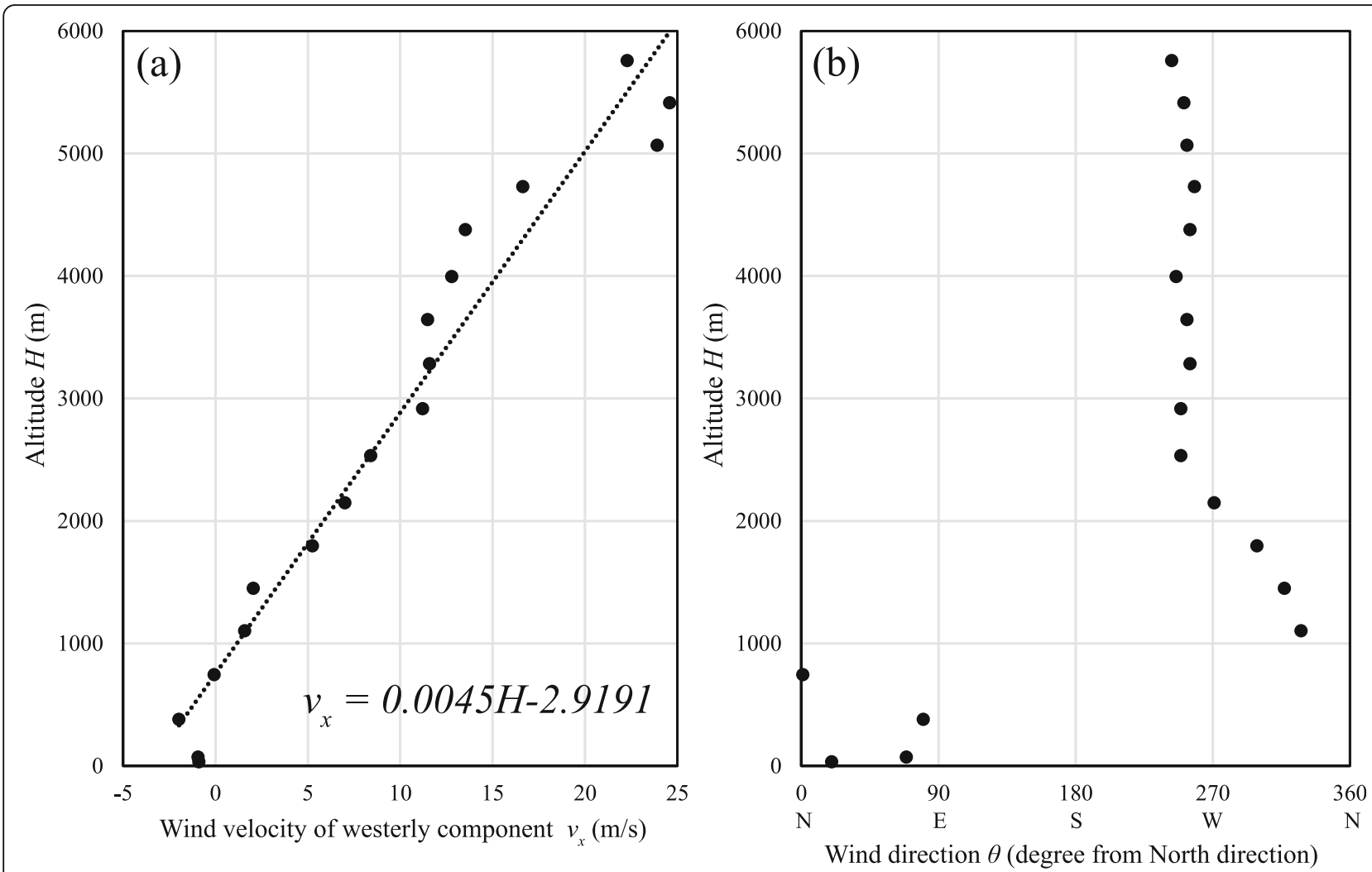

Fig. 3 Height profile of $\mathbf{a}$ velocity and $\mathbf{b}$ direction of upper wind at Kagoshima region meteorological station. The dashed line in $\mathbf{a}$ is the result of linear fitting of the relationship between wind velocity and height

\section{Field observations}

We conducted field observations consisting of highspeed camera imaging of airborne ash particles and high-temporal resolution sampling of falling ash (Fig. 1c). The field site was located approximately $3.5 \mathrm{~km}$ east of the Showa crater (Fig. 1a) and was roughly under the dispersal axis of the volcanic cloud. The consideration on location of the dispersal axis is also supported by eastward wind direction at height of 2000-3000 m a.s.l. around Kagoshima area as reported by JMA (Fig. 3) (http://www.data.jma.go.jp/obd/stats/etrn/index.php).

\section{High-speed camera imaging}

To estimate the aerodynamic properties of falling ash particles, we observed airborne ash particles using a high-speed camera (Fig. 1c and Additional file 1: Movie S1, Additional file 2: Movie S2, and Additional file 3: Movie S3). The monochromatic high-speed camera (HAS-L2M by Ditect Co. Ltd.) was used to obtain video footage at $3000 \mathrm{fps}$, with an image size of 180 pixels $\times$ 190 pixels. The lens used had a focal length of $50 \mathrm{~mm}$ and an aperture of $\mathrm{f} / 1.4$, providing a focal distance of 50 $\mathrm{cm}$, an image resolution of $0.095 \mathrm{~mm} / \mathrm{pixel}$, and 4.75 $\mathrm{mm}$ of focal depth. The aperture was set as large as possible to reduce the focal depth of the images so as to minimize the particle size analysis error. Calibration using checkerboard panels showed that the image distortion in the captured images was negligible for the analyses. The camera was set on a tripod to horizontally capture the falling ash, and a white background was selected for the image background. During the eruption, we recorded three footages from 10:57, 11:33, and 12:00. These footages are labeled HSC1057, 1133, and 1200, respectively. Each piece of footage lasted for approximately $1 \mathrm{~min}$, with the duration being limited by camera memory and computer processing power. The computer transfer time forced an interval of approximately $30 \mathrm{~min}$ between recordings.

The captured footage was exported as a time series of 8-bit bitmap files, and the software package ImageJ was used to estimate the size and vertical falling velocity of in-flight particles. We identified just-focused particles in the images and made binary images of the particles by applying a tone threshold. Using an image resolution of $0.095 \mathrm{~mm} /$ pixel, the lengths $(l)$ of major and minor axes of each filmed particle were estimated, and the $2 \mathrm{D}$ equivalent diameter was calculated using $D=$ $\sqrt{l_{\text {minor }} \times l_{\text {major }}}$. Falling velocities of ash particles were estimated using the change in vertical position of 
particle centroids using a time sequence of binary images at a frame rate of $3000 \mathrm{fps}$.

Errors on the estimated particle falling velocities were estimated from the uncertainty in the particle centroid positions. Using an exposure time of $333 \mu$ s with a falling velocity of $0.2-7.0 \mathrm{~m} / \mathrm{s}$, we multiplied the exposure time and falling velocity to estimate the uncertainty of the particle centroid positions at $67-2300 \mu \mathrm{m}$. Thus, the percentage error in the centroid positions relative to the falling distance taken from high-speed camera imagery $(18 \mathrm{~mm})$ is estimated at $0.37-12 \%(100 \times$ uncertainty/ height of the image), with faster-falling particles having a larger relative error which was estimated to \pm 0.001 $0.910 \mathrm{~m} / \mathrm{s}$ for the range of falling velocities.

\section{High-temporal resolution sampling}

Additionally, we sampled falling ash particles at hightemporal resolution (Table 1) simultaneously with the high-speed camera imaging. The sampling was performed from 10:57 to 12:12 with time intervals of $1 \mathrm{~min}$ for 10:57-11:07 and $5 \mathrm{~min}$ for 11:07-12:12. Two plastic trays with opening area of $38 \mathrm{~cm} \times 52 \mathrm{~cm}$ were used for the sampling. We alternated the two trays to enable continuous sampling of the falling ash particles. Since the sampling was held under calm weather condition, contamination from old deposit by wind resuspension is highly unlikely and our careful cleaning of trays avoided contamination from the old sampling. Unfortunately, the ash sample collected during 11:30-11:35 was lost while being transferred to a plastic bag for the sample.

The ash falling rates were calculated by dividing the accumulated mass of fallen ash by the duration of sampling and the area of the plastic trays. The accumulated mass was measured using precise scales (error of $1.0 \times$ $10^{-5} \mathrm{~g}$; Shimadzu AUW220D) in National Research Institute for Earth Science and Disaster Resilience, Tsukuba, Japan. The error in sampling duration is less than $10 \mathrm{~s}$.

\section{Grain size analysis}

In order to examine in detail the sedimentation process of falling ash particles, we analyzed the GSD of 22 ash samples obtained at regular intervals throughout the ashfall. The grain size analyses were performed using a Partica LA-960 instrument from HORIBA at the Geological Survey of Japan, Tsukuba. The grain size analyzer measures particle sizes ranging from 0.01 to $3000 \mu \mathrm{m}$ using laser diffraction. The ash samples were dispersed

Table 1 Summary of high-temporal sampling

\begin{tabular}{|c|c|c|c|c|}
\hline Sample name & Beginning time (JST) & End time (JST) & Interval [min] & Ash falling rate $\left[\mathrm{g} \mathrm{min}^{-1} \mathrm{~m}^{-2}\right]$ \\
\hline sj0326-01 & $10: 57$ & $10: 58$ & 1 & 92.85 \\
\hline sj0326-02 & 10:58 & 10:59 & 1 & 54.92 \\
\hline sj0326-03 & 10:59 & 11:00 & 1 & 33.12 \\
\hline sj0326-04 & 11:00 & 11:01 & 1 & 13.14 \\
\hline sj0326-05 & 11:01 & 11:02 & 1 & 10.08 \\
\hline sj0326-06 & 11:02 & 11:03 & 1 & 7.98 \\
\hline sj0326-07 & 11:03 & 11:04 & 1 & 0.40 \\
\hline sj0326-08 & 11:04 & 11:05 & 1 & 1.13 \\
\hline sj0326-09 & 11:05 & 11:06 & 1 & 1.53 \\
\hline sj0326-10 & 11:06 & 11:07 & 1 & 2.77 \\
\hline sj0326-11 & 11:07 & $11: 12$ & 5 & 2.48 \\
\hline sj0326-12 & $11: 12$ & $11: 17$ & 5 & 1.38 \\
\hline sj0326-13 & 11:17 & $11: 22$ & 5 & 0.65 \\
\hline sj0326-14 & $11: 22$ & $11: 27$ & 5 & 0.23 \\
\hline No sample & $11: 27$ & 11:32 & 5 & \\
\hline sj0326-15 & $11: 32$ & $11: 37$ & 5 & 0.12 \\
\hline sj0326-16 & $11: 37$ & $11: 42$ & 5 & 0.15 \\
\hline sj0326-17 & $11: 42$ & $11: 47$ & 5 & 0.91 \\
\hline sj0326-18 & $11: 47$ & $11: 52$ & 5 & 3.26 \\
\hline sj0326-19 & $11: 52$ & $11: 57$ & 5 & 3.06 \\
\hline sj0326-20 & $11: 57$ & 12:02 & 5 & 0.92 \\
\hline sj0326-21 & 12:02 & 12:07 & 5 & 0.55 \\
\hline sj0326-22 & 12:07 & $12: 12$ & 5 & 0.25 \\
\hline
\end{tabular}


in distilled water before the analyses were performed. The plastic bags were washed using distilled water to ensure measurement of very fine particles.

We first used the GRADISTAT program (Blott and Pye 2001) to analyze GSDs. The median size $\left(M_{d}\right)$ and standard deviation $\left(S_{d}\right)$ were calculated using the graphical method of Folk and Ward (1957). Although these parameters can be calculated only in lognormal GSDs with a unimodal shape, we characterized the GSDs which include bimodal and trimodal distributions by using these parameters for convenience in presentation (Evans et al. 2009).

Multiple lognormal curves were fitted to examine subpopulations within the GSDs. The fitting was done using PeakFit software (Hulinks Inc.). PeakFit deconvolved subpopulations from the GSDs using a basic function with a linear baseline based on least squares regression between the results of analysis and the fitting calculation. We tested lognormal, Weibull, and Rosin-Rammler distributions as the basic functions for fitting (Eychenne et al. 2012; Sheridan et al. 1987; Wohletz et al. 1989) and applied lognormal distributions because of their simple expression. The number of subpopulations was determined by the number of apparent peaks found in the GSDs. We named these subpopulations SP\#1, SP\#2, and SP\#3 in descending order of their peak amplitudes. The $M_{d}$ and $S_{d}$ values of the subpopulations were expressed using the $\Phi$ scale $\left(=-\log _{2} d ; d\right.$ is particle size in millimeters).

\section{Results and discussion}

\section{Time series of the ash falling rate}

The ash falling rate at the field site varied during the ashfall (Fig. 4). The ashfall at the field site started at 10: 57 (13 min after the first eruption onset) and ceased at 12:12. The ash falling rate reached a maximum during the first $1 \mathrm{~min}$ (10:57-10:58) and decreased during the following $7 \mathrm{~min}$ (10:57-11:04). The rate then recovered and showed a secondary peak $10 \mathrm{~min}$ after the onset of ashfall (11:07-11:08), followed by another decrease (11: 08-11:37). The rate gradually increased to reach a third peak (11:37-11:52) and finally decreased until the end of the ashfall (11:52-12:12). During the field observation, we observed the fallout of ash aggregates which were broken on the impact with the ground surface at least between 11:45 and 11:46 (Additional file 4: Movie S4). However, the type of aggregate observed in this study could not be determined because we did not perform high-speed and high-resolution camera imaging of the impact of aggregates (Bagheri et al. 2016).

\section{Aerodynamic properties of falling ash}

Here, we present the results of high-speed camera imaging of airborne ash particles. Analysis of the images shows that particle size ranged from 0.12 to $2.2 \mathrm{~mm}$ and that falling velocity ranged from 0.2 to $7.0 \mathrm{~m} / \mathrm{s}$ (Fig. $5 \mathrm{a}$ ). Size and falling ash velocity decreased from HSC1057 to HSC1133 and HSC1200. The size-velocity relationship is consistent with the results presented by Bagheri et al. (2016). Their results fall between our results for HSC1057 and others (HSC1133 and HSC1200) (Fig. 5a). The relationship is also similar to that obtained for the 2010 eruption of Eyjafjallajökull volcano (Taddeucci et al. 2011). Specifically, the size-velocity relationship found in HSC1057 overlaps the results for individual particles from Eyjafjallajökull, and the relationship identified in HSC1133 and HSC1200 is similar to that for aggregated particles for Eyjafjallajökull (Taddeucci et al. 2011).

The Reynolds number $\left(R_{e}\right.$ : ratio of inertia to viscous force) and drag coefficient $\left(C_{d}\right.$ : drag force of a fluid on a moving particle) of falling particles were calculated from the size and velocity of ash particles. For the calculation, we applied the model of Wilson and Huang (1979) using:

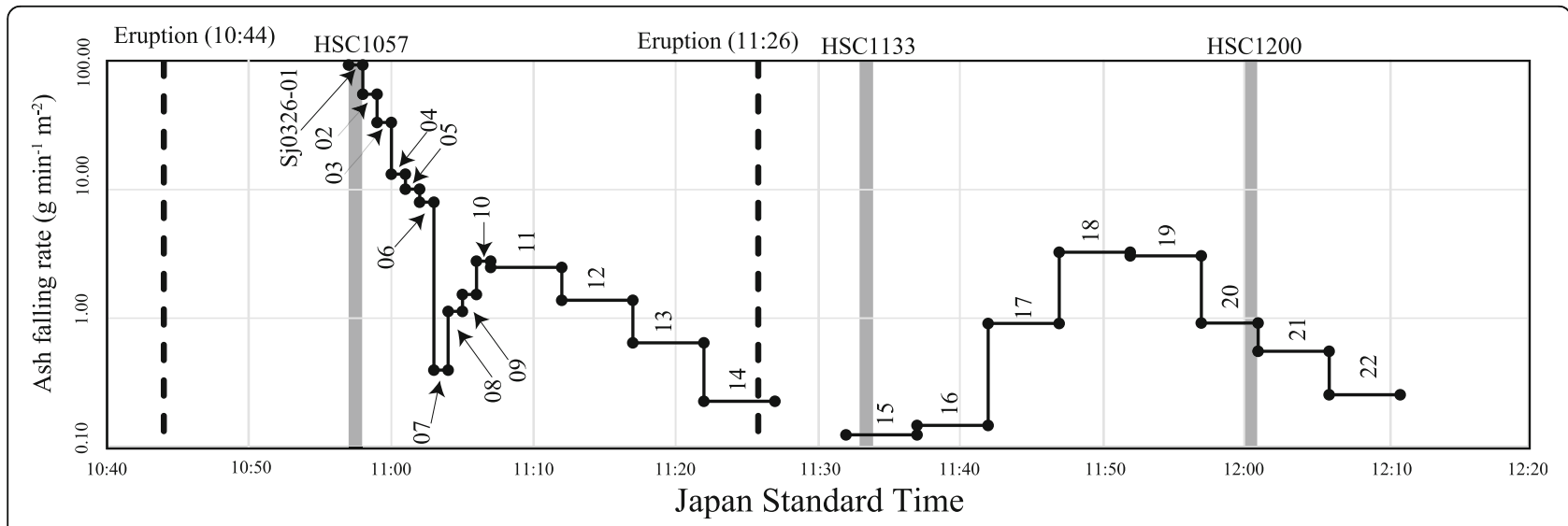

Fig. 4 Timeline of field observations and temporal variation in ash falling rate at the field site. Note that logarithmic scale in the vertical axis. Numbers refer to sample number 

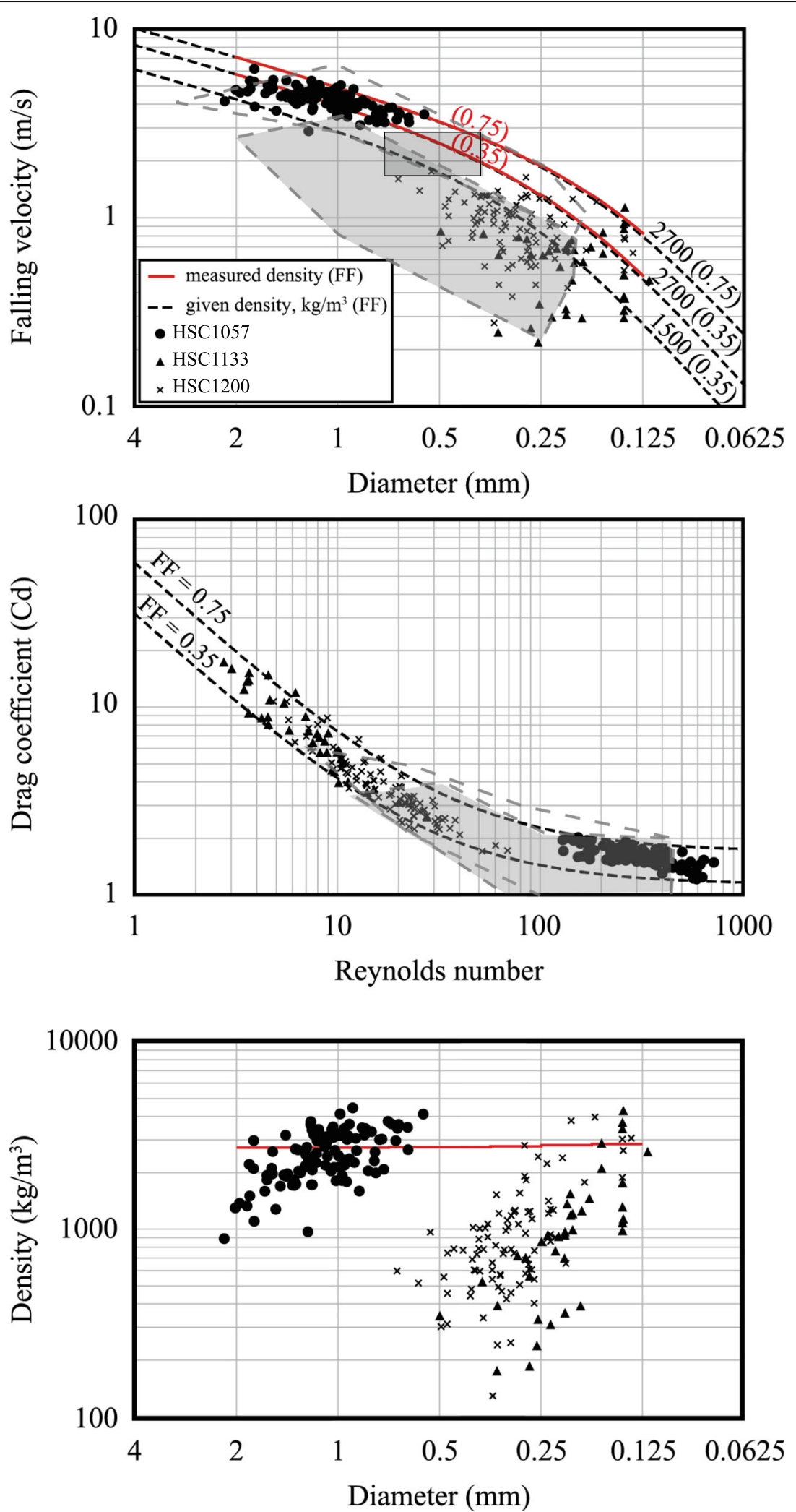

Fig. 5 (See legend on next page.) 
(See figure on previous page.)

Fig. 5 Aerodynamic properties of falling ash particles obtained using high-speed camera imaging. Black circles, triangles, and crosses show the results of footages HSC1057, HSC1133, and HSC1200, respectively. a Relationship between falling velocity and diameter of ash particles. Curves represent the model of Wilson and Huang (1979), and the corresponding density and form factor $\left(\mathrm{FF}=\left(I_{\text {intermediate }}+I_{\text {minor }}\right) /\left(2 \times I_{\text {major }}\right)\right)$ values are shown. Solid red curves were obtained based on density variation in the ash deposit measured using a helium pycnometer. Dashed black curves were calculated by the given constant density. Gray square shading indicates the range in particle size and velocity of the aggregates in Sakurajima volcano, as reported in Bagheri et al. (2016). Colorless and gray areas enclosed by gray dash lines indicate the individual and aggregate particles from Eyjafjallajökull volcano, respectively (Taddeucci et al. 2011). b Relationship between Reynolds number ( $R_{e}$ ) and drag coefficient $\left(C_{d}\right)$. Dashed curves show the model of Wilson and Huang (1979) with form factors of 0.35 and 0.75 . Colorless and gray areas enclosed by gray dash lines indicate the individual and aggregate particles from Eyjafjallajökull volcano, respectively (Taddeucci et al. 2011). c Density and diameter of falling ash particles calculated from Eqs. (1), (2), and (3). The solid red line represents density variation in the ash deposit, as measured using a helium pycnometer

$$
\begin{aligned}
R e & =\rho v L / \eta \\
C_{d} & =\frac{24}{\operatorname{Re}} F F^{-0.828}+2 \sqrt{1.07-F F}
\end{aligned}
$$

where $\rho$ is the density of the medium; $v$ is falling velocity; $L$ is the characteristic length of the particle; $\eta$ is the viscosity of the medium; and FF is the form factor calculated by the major, intermediate, and minor lengths of the particle: $F F=\left(l_{\text {intermediate }}+l_{\text {minor }}\right) /\left(2 \times l_{\text {major }}\right)$. Recently, Kozono et al. (2019) suggested that the relationship between size and velocity of ash particles with size of $<0.32 \mathrm{~mm}$ is explained by the model of Wilson and Huang (1979) for the Vulcanian eruptions at Sakurajima volcano. We used the velocity and major and minor lengths of falling ash particles in the $2 \mathrm{D}$ images to calculate values of $R_{e}$ and $C_{d}$. The equivalent diameter $D$ was used for the characteristic length $L$ and intermediate axis in the calculation. The estimated value of $F F$ ranged from 0.25 to 0.75 with 0.56 in average. The estimated values of $R_{e}$ and $C_{d}$ ranged from 2 to 70 and 1 to 11 , respectively (Fig. 5b). Both the $R_{e}$ and $C_{d}$ values decreased from HSC1057 to HSC1133 and HSC1200. The trend of the $R_{e}$ and $C_{d}$ covers those of the 2010 eruption at Eyjafjallajökull volcano (Taddeucci et al. 2011).

The density of airborne ash particles $\left(\rho_{s}\right)$ was derived using a modified equation from Dellino et al. (2005), which balances the downward gravitational force $(g)$ and the drag force due to air resistance around a spherical particle $\left(C_{d}\right)$ :

$$
\rho_{s}=\frac{3 C_{d} \rho v^{2}}{4 g L}+\rho
$$

The calculated density ranged from 130 to $4400 \mathrm{~kg}$ $\mathrm{m}^{-3}$, which spans the mean density of ash particles obtained using a helium pycnometer $\left(=2700 \pm 50 \mathrm{~kg} \mathrm{~m}^{-3}\right.$; see Additional file 5: Text S1). The maximum calculated density $\left(4400 \mathrm{~kg} \mathrm{~m}^{-3}\right)$ is lower than the highest possible density of an ash particle, which is approximately 5200 $\mathrm{kg} \mathrm{m}^{-3}$ derived from the inclusion of magnetite. The minimum calculated density $\left(130 \mathrm{~kg} \mathrm{~m}^{-3}\right)$ is one order of magnitude lower than that of vesicular glass (minimum of $1500 \mathrm{~kg} \mathrm{~m}^{-3}$; Miwa et al. 2013). The calculated density decreased from HSC1057 (mean $=2500 \mathrm{~kg} \mathrm{~m}^{-3}$, range $=$ $890-4400 \mathrm{~kg} \mathrm{~m}^{-3}$ ) to HSC1133 (mean $=1220 \mathrm{~kg} \mathrm{~m}^{-3}$, range $=180-4270 \mathrm{~kg} \mathrm{~m}^{-3}$ ) and to HSC1200 (mean = $1030 \mathrm{~kg} \mathrm{~m}^{-3}$, range $=130-3980 \mathrm{~kg} \mathrm{~m}^{-3}$ ) (Fig. 5c). Within the footage for HSC1057, HSC1133, and HSC1200, the percentage of particles with a density of $<1500 \mathrm{~kg} \mathrm{~m}^{-3}$ was $10 \mathrm{vol} . \%$, $80 \mathrm{vol} . \%$, and $80 \mathrm{vol} . \%$ of the total volume, respectively.

The numbers of falling particles filmed by the HSC imaging qualitatively decreases from HSC1057 to HSC1133 and HSC1200. This seems to be consistent with the time series of the ash falling rate (Fig. 4).

\section{Grain size distributions}

Table 2 summarizes the results of the GSD analyses of the collected particles. The ash samples exhibited unimodal, bimodal, or trimodal GSDs and changed through the course of the ashfall (Fig. 6). Sampled grain sizes ranged from $-1.5 \Phi$ to $8 \Phi(2.8 \mathrm{~mm}$ to $3.9 \mu \mathrm{m})$. For samples from 10:57 to 11:37, the GSDs showed bimodal character in 10:57-10:59, unimodal distributions from $10: 59$ to $11: 04$, and bimodal distributions from 11:04 to $11: 37$. For samples from 11:37 to $12: 12$, trimodal distributions were found in 11:37-11:47 and bimodal distributions in 11:47-12:12.

$M_{d}$ and $S_{d}$ values of the bulk samples are summarized in Table 2. $M_{d}$ ranged from -0.01 to $3.06 \Phi$, ranging from very fine to very coarse ash. $S_{d}$ ranged from 0.35 to $1.55 \Phi$, ranging from well to poorly sorted. We also identified temporal variations in $M_{d}$ and $S_{d}$ values for the subpopulations (Fig. 7). For the first subpopulation (SP\#1), $M_{d}$ generally decreased over time, although there is a decreasing step of $M_{d}$ value in 11:37-11:42. $S_{d}$ showed very little variation throughout the ashfall. For the second subpopulation (SP\#2), $M_{d}$ gradually increased from 10:57 to 11:37, showed a stepwise increase at 11: $37-11: 42$, and then gradually decreased until the end of the ashfall. The fraction of grains that fell within this second subpopulation generally increased from 10:57 to 11:37 and then decreased from 11:37 to the end of the ashfall. $S_{d}$ for SP\#2 gradually increased from 10:57 to 11: 
Table 2 Summary of grain size analysis

\begin{tabular}{|c|c|c|c|c|c|c|c|c|c|c|c|}
\hline & Bulk & & SP\#1 & & & SP\#2 & & & SP\#3 & & \\
\hline & Md phi & $\sigma$ phi & Md phi & $\sigma$ phi & Areal\% & Md phi & $\sigma$ phi & Areal\% & Md phi & $\sigma$ phi & Areal\% \\
\hline sj0326-01 & -0.01 & 0.47 & 0.13 & 0.38 & 99.6 & 7.17 & 0.30 & 0.4 & & & \\
\hline sj0326-02 & 0.19 & 0.35 & 0.30 & 0.32 & 99.5 & 7.26 & 0.27 & 0.5 & & & \\
\hline sj0326-03 & 0.44 & 0.40 & 0.56 & 0.34 & 100.0 & & & & & & \\
\hline sj0326-04 & 0.65 & 0.38 & 0.76 & 0.34 & 100.0 & & & & & & \\
\hline sj0326-05 & 0.77 & 0.40 & 0.89 & 0.36 & 100.0 & & & & & & \\
\hline sj0326-06 & 0.92 & 0.41 & 1.02 & 0.37 & 99.6 & 7.14 & 0.27 & 0.4 & & & \\
\hline sj0326-07 & 0.88 & 0.43 & 0.99 & 0.39 & 100.0 & & & & & & \\
\hline sj0326-08 & 1.04 & 0.44 & 1.15 & 0.39 & 99.3 & 6.33 & 0.39 & 0.7 & & & \\
\hline sj0326-09 & 1.17 & 0.45 & 1.27 & 0.40 & 98.7 & 6.37 & 0.48 & 1.3 & & & \\
\hline sj0326-10 & 1.24 & 0.45 & 1.38 & 0.35 & 99.5 & 6.34 & 0.35 & 0.5 & & & \\
\hline sj0326-11 & 1.51 & 0.50 & 1.60 & 0.43 & 97.3 & 6.58 & 0.59 & 2.7 & & & \\
\hline sj0326-12 & 2.04 & 0.96 & 2.09 & 0.45 & 92.3 & 5.87 & 0.83 & 7.7 & & & \\
\hline sj0326-13 & 2.13 & 1.15 & 2.13 & 0.46 & 85.1 & 5.75 & 1.08 & 14.9 & & & \\
\hline sj0326-14 & 3.06 & 1.55 & 2.79 & 0.39 & 65.0 & 5.93 & 0.88 & 35.0 & & & \\
\hline sj0326-15 & 2.78 & 1.37 & 2.72 & 0.38 & 76.4 & 5.88 & 1.26 & 23.6 & & & \\
\hline sj0326-16 & 1.14 & 1.47 & 0.90 & 0.44 & 62.3 & 2.56 & 0.73 & 29.3 & 6.04 & 0.82 & 8.4 \\
\hline sj0326-17 & 1.14 & 1.30 & 1.09 & 0.45 & 78.3 & 2.78 & 0.86 & 15.9 & 6.39 & 0.73 & 5.8 \\
\hline sj0326-18 & 1.50 & 1.18 & 1.51 & 0.48 & 86.9 & 3.14 & 0.61 & 6.7 & 6.50 & 0.73 & 6.4 \\
\hline sj0326-19 & 1.83 & 1.04 & 1.86 & 0.49 & 90.0 & 3.34 & 0.43 & 4.2 & 6.37 & 0.74 & 5.7 \\
\hline sj0326-20 & 2.22 & 1.06 & 2.24 & 0.47 & 88.3 & 3.68 & 0.49 & 4.2 & 6.26 & 0.67 & 7.4 \\
\hline sj0326-21 & 2.44 & 0.96 & 2.49 & 0.43 & 90.1 & 3.83 & 0.49 & 3.5 & 6.32 & 0.66 & 6.4 \\
\hline sj0326-22 & 2.64 & 0.93 & 2.68 & 0.39 & 88.4 & 3.64 & 0.44 & 4.6 & 6.41 & 0.61 & 7.0 \\
\hline
\end{tabular}

37 and then decreased. The third subpopulation (SP\#3) started to appear only from 11:37 onwards, and its $M_{d}$ value and fraction remained fairly constant from 11:37 until the end of the ashfall. $S_{d}$ of SP\#3 decreased slightly throughout the ashfall. Sample collected in 11:37-11:42 marked a change in median grain size for all three subpopulations, with $M_{d}$ decreasing from that sample to the end of ashfall.

All GSDs obtained by high-speed imaging exhibited unimodal distributions (Fig. 8). We found modal grain sizes of $-0.77 \Phi, 1.52 \Phi$, and $1.32 \Phi$ for HSC1057, HSC1133, and HSC1200, respectively. The GSDs from the samples that were simultaneously collected exhibited bimodal distributions, with this bimodality (compared with the unimodality of airborne particles) implying that the size distribution of particles changed after colliding with the ground surface.

\section{Sedimentation process of ashfall during a vulcanian eruption}

The results of the GSD analysis and high-speed camera imaging demonstrate that the sedimentation process during Vulcanian eruptions at Sakurajima volcano is controlled mainly by size-dependent segregation of ash particles from discrete transient eruption plumes. The median grain size of SP\#1, with corresponds to $70-99 \%$ of falling ash, decreased after each of the two eruptions (Fig. 7), indicating the size-depending segregation of ash particles in which larger particles having higher terminal velocity fall earlier from the volcanic cloud than smaller particles. This decrease in particle size was also identified in the GSD obtained by highspeed camera imaging where the mode value of particle size is smaller in HSC1133 than that in HSC1057 (Fig. 8). Trimodal GSDs found after 11:37 represent the arrival of falling ash particles from the second thermal cloud. We conclude that the ash particles were separately supplied from two distinct thermals from each eruption, as inferred from the continuous trend of SP\#1 before and SP\#2 after 11: 37 (Fig. 7a).

We examined the relationship between particle size and its arrival time by using a simple model for the volcanic thermal cloud, which is approximated as a singlerelease source of ash particles at a constant height with an effect of advection by horizontal wind (Fig. 9). In this 


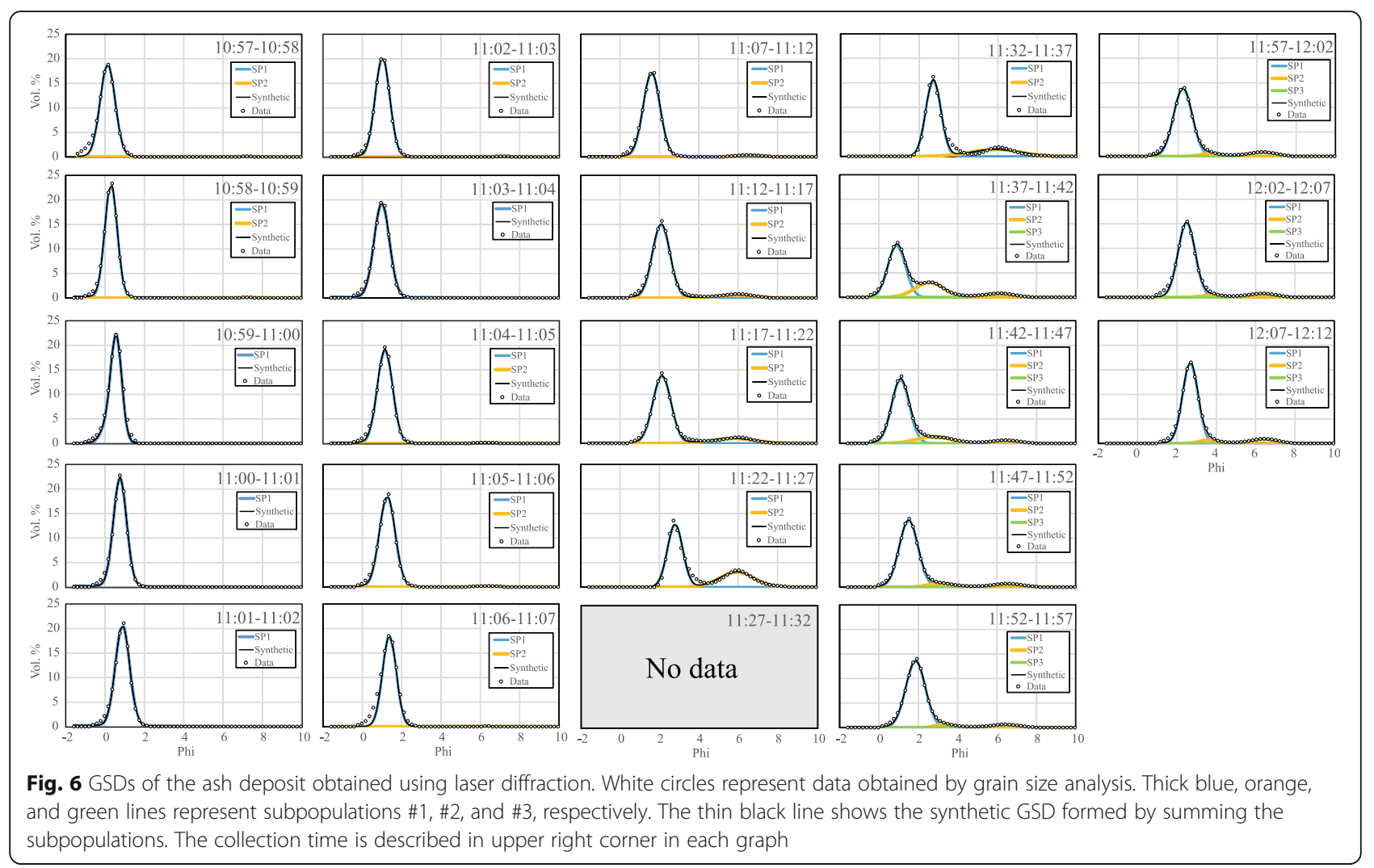

case, the horizontal $(\mathrm{L})$ and vertical $(\mathrm{H})$ locations of the falling particle from the release source at time $(t)$ are given as

$$
\begin{aligned}
& L=v_{x}\left(t-t_{0}-\Delta t\right) \\
& H=H_{0}-v_{z}\left(t-t_{0}-\Delta t\right)
\end{aligned}
$$

where $H_{O}$ is a height of the release source of falling particles from the observation point, $t_{0}$ is the onset time of eruption, and $\Delta t$ is the time required for the height of the release source to reach the height $H_{0}$. The $v_{x}$ and $v_{z}$ are horizontal and vertical (falling) velocities of the particles, respectively. $v_{x}$ is expressed as function of $H$, which is derived from the height profile of westerly component of upper wind at 9:00 of 26 March 2016 in Kagoshima regional meteorological station (Meteorological data set published by JMA; http://www.data.jma.go.jp/obd/stats/ etrn/index.php) (Fig. 3), and approximated to

$$
v_{x}=0.0045 H-2.9191
$$

By combining the Eqs. (4), (5), and (6) with the relationship between the falling velocity $\left(v_{z}\right)$ and particle size described as Eqs. (1), (2), and (3) (Wilson and Huang 1979), we calculated the particle size likely to fall at the observation point at a particular time. The location of observation point is set to $L=3500 \mathrm{~m}$ and $H=0 \mathrm{~m}$. The values of $H_{0}$ for the first and second eruptions are 3500 $\mathrm{m}$ and $2900 \mathrm{~m}$, respectively, from the height difference between volcanic cloud and the observation point. $\Delta t$ is $180 \mathrm{~s}$ (Fig. 2), and the modeled particle density $2700 \mathrm{~kg}$ $\mathrm{m}^{-3}$. This model does not take into account a complex wind field in proximal area of volcano by orographic effects (e.g., Poulidis et al. 2017), because there is no dense observation network for wind condition to capture such a detailed wind field.

The calculation result mostly explains the trend of temporal variation in the median grain size of SP\#1 during both the first and second eruptions within the standard deviations (Fig. 7). This finding indicates that a discrete, initially homogeneous batch of ash from a discrete volcanic cloud is a plausible source model for tephra sedimentation during a Vulcanian eruption. This consideration is consistent with a result of detailed observation of volcanic plume at Sakurajima volcano by using high-speed (visible and thermal) camera, in which ring vortex at the head of transient plume was interpreted as the main carrier of tephra (Tournigand et al. 2017).

It should be noted that our model does not account for the effects of multiple release sources in the eruption cloud (e.g., Folch 2012). The variation of physical properties (such as grain size concentration of tephra) within the eruptive column which determines the parameters of 


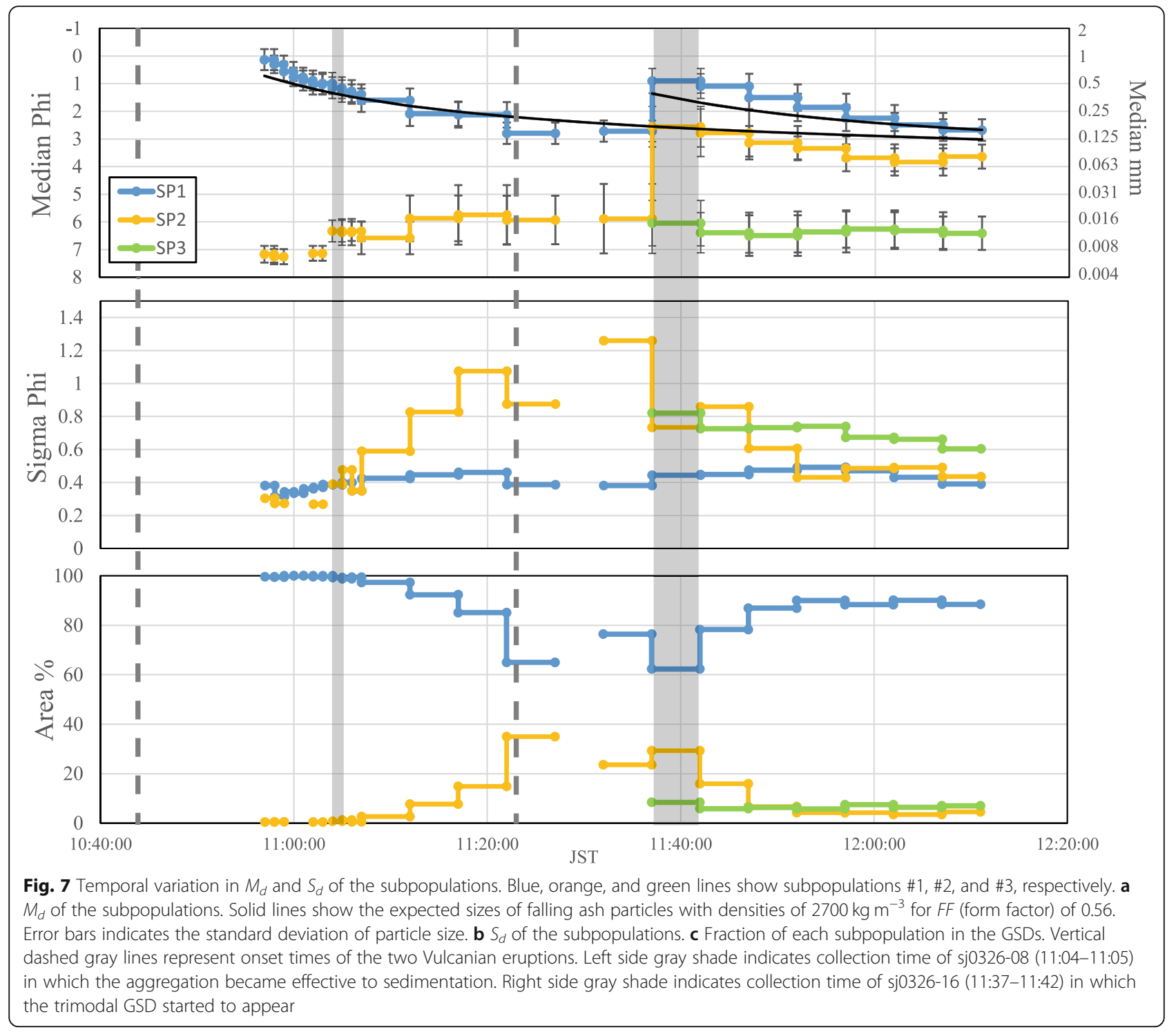

multi-release sources of tephra dispersal has not been well constrained in the actual eruptions (e.g., Shimbori 2016), and our field site was limited to one point (approximately $3.5 \mathrm{~km}$ from the vent), for which is not appropriate to apply such a model. This effect needs to be considered for building a more sophisticated model for tephra transport in Vulcanian eruptions by using data from dense observation network for the falling ash.

The contribution of ash aggregates to ashfall dynamics becomes significant during the course of ashfall following a Vulcanian eruption. We could observe the fallout of ash aggregates which were broken at the impact on the ground surface at least between 11:45 and 11:46 (Additional file 4: Movie S4). The measured change in the median grain size of SP\#1 can be explained by the size-dependent segregation of ash particles from the volcanic plume. Specifically, $M_{d}$ was finer than the modeled individual particle size following the first eruption (Fig. 7). This suggests that the falling velocity of ash particles increased as a result of aggregate formation. High-speed camera imaging showed that volume fractions of falling ash particles with density of $<1500 \mathrm{~kg} \mathrm{~m}^{-3}$ were higher in the ashfalls of 11:33-11:34 (HSC1133) and 12:00-12: 01 (HSC1200) than that of 10:57-10:58 (HSC1057) (Fig. $5)$. The low-density particles $\left(<1500 \mathrm{~kg} \mathrm{~m}^{-3}\right)$ are interpreted as ash aggregates, since the likely lowest density of an individual particle at Sakurajima volcano is approximately $1500 \mathrm{~kg} \mathrm{~m}^{-3}$ (for particles with approximately $40 \%$ vesicularity) (Miwa et al. 2013). This low density is similar to that of an experimental or natural ash aggregate with abundant pores (James et al. 2003; Taddeucci et al. 2011), thus supporting the interpretation. Bimodality in GSDs has been interpreted as evidence of ash aggregation, which increases the terminal 


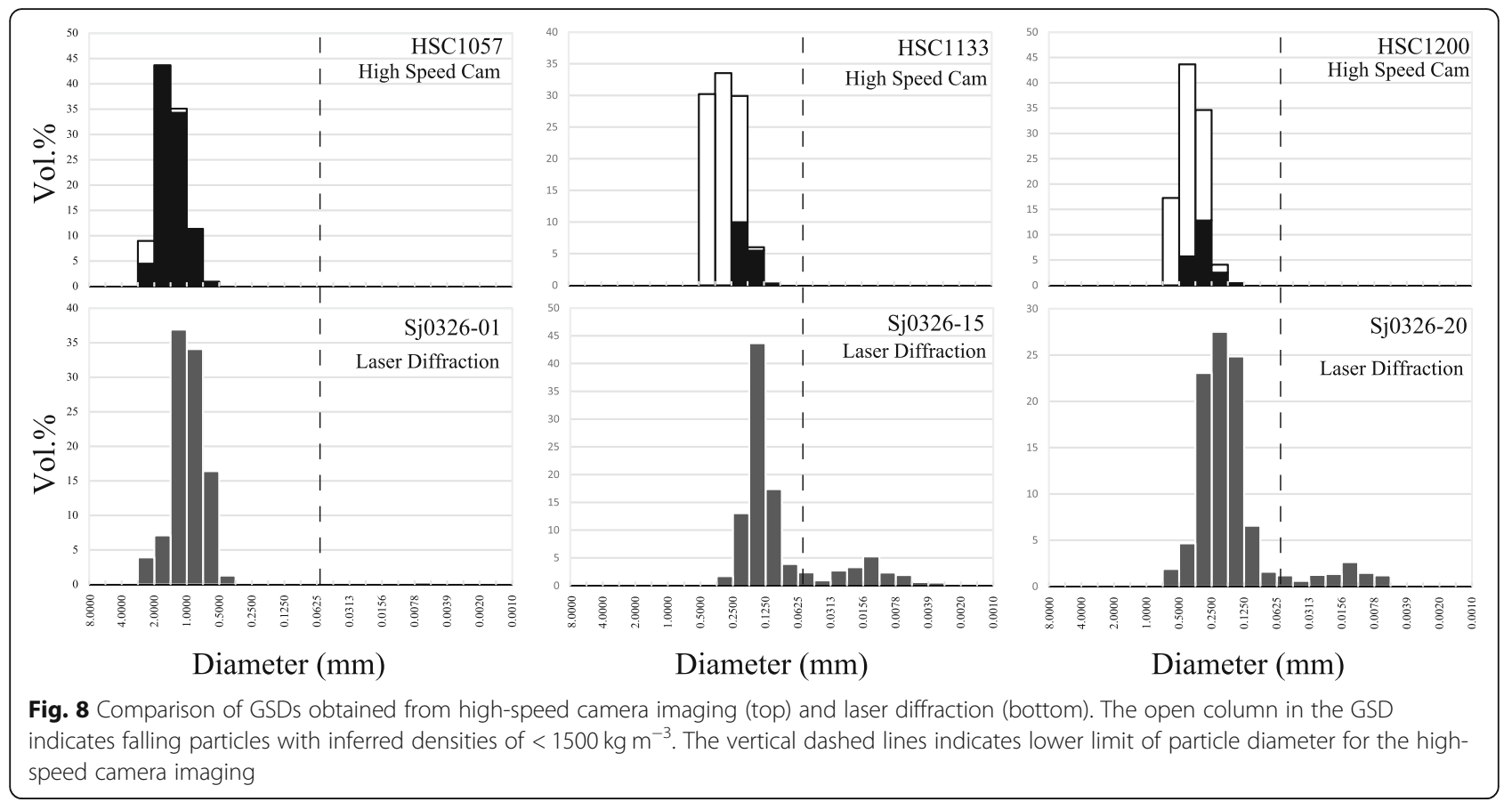

velocity of fine ash particles (Brazier et al. 1983; Carey and Sigurdsson 1982). Within the measured bimodal distributions, the finer SP\#2 is considered to represent the fine-aggregate component (Bagheri et al. 2016; Brazier et al. 1983; Schumacher 1994). The fraction of the overall GSD constituted by SP\#2 increased $8 \mathrm{~min}$ after the start of ashfall produced by the first eruption (Fig. 7c). The fraction of SP\#2 increased particularly in 11: $32-11: 37$, in which over 80 vol.\% of falling ash particles with size $>3 \phi$ had a density of $<1500 \mathrm{~kg} \mathrm{~m}^{-3}$ (Fig. 8). This suggests that the aggregate content increased $8 \mathrm{~min}$ and peaked $40 \mathrm{~min}$ after the start of the ashfall. Bagheri et al. (2016) also reported an increase in ash aggregates $10 \mathrm{~min}$ after the commencement of ashfall following a

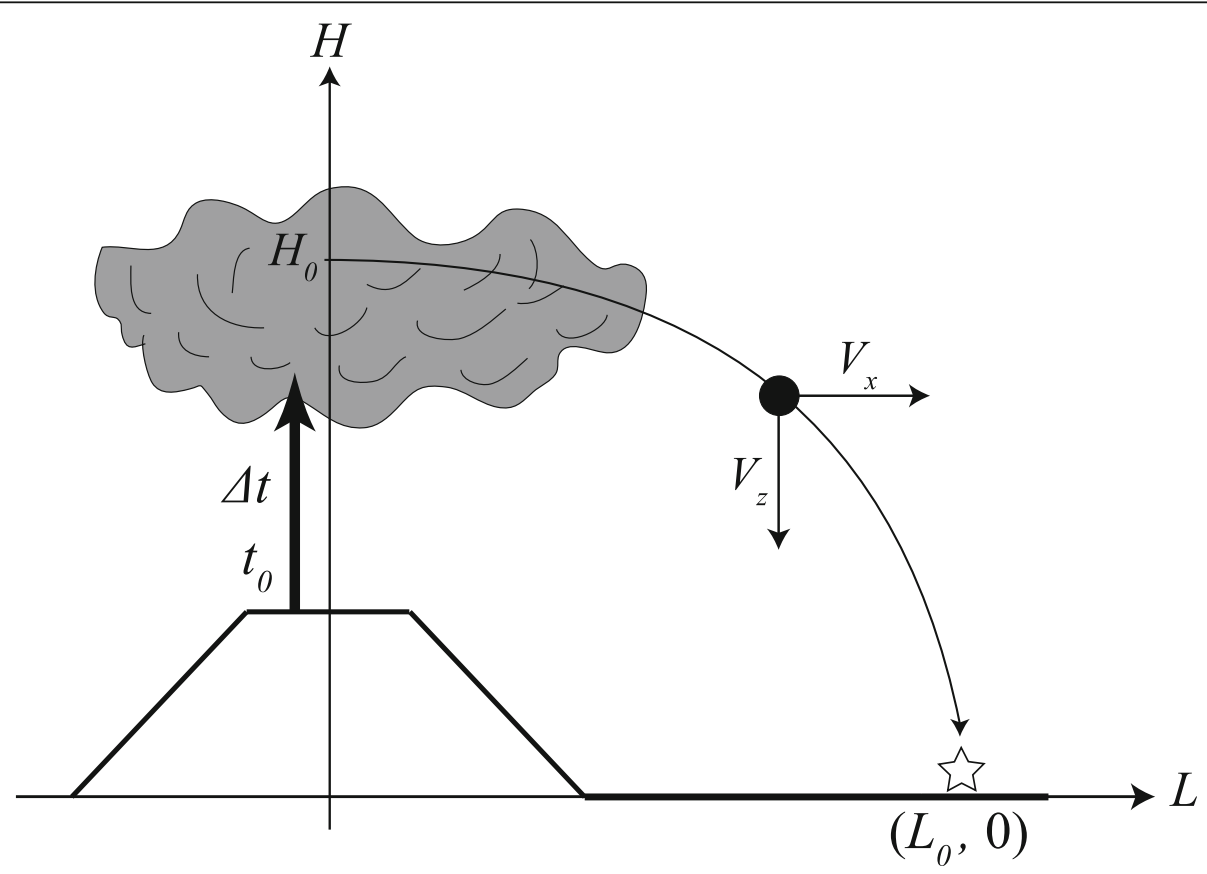

Fig. 9 Schematic diagram of the relationship between ash particle size and its arrival time 
Vulcanian eruption at Sakurajima volcano. Thus, we suggest that the increase in ash aggregation of falling ash particles may occur $\sim 10 \mathrm{~min}$ after the start of ashfall in proximal area during normal Vulcanian eruptions emitting volcanic clouds with $1000-2000 \mathrm{~m}$ of height at Sakurajima volcano. It is noted that particles of SP\#2 and SP\#3 never fell as individual particles within the observation time. The time required for the individual particles of SP\#2 and SP\#3 with size of 6-7 phi $(8-16 \mu \mathrm{m})$ to reach the field site from the vent can be calculated by dividing the difference of altitude between the vent and field site $(900 \mathrm{~m})$ with the falling velocity of such particle (around $0.001 \mathrm{~m} / \mathrm{s}$ ) (Wilson and Huang 1979). Therefore, the time required is calculated to approximately $250 \mathrm{~h}$ and is clearly ruled out from the result of our observation in which total time of observation was approximately $1.5 \mathrm{~h}$. Moreover, we did not observe any pyroclastic density current which could be the source of fine ash particles during the observation of the eruption (Fig. 2).

Temporal variation in the rate of falling ash particles during the course of a Vulcanian eruption is affected by ash aggregation. The ash falling rate decreased rapidly during the first $8 \mathrm{~min}$ and then increased (Fig. 4). This recovery of the ash falling rate was accompanied by a slight increase in the volume fraction and $S_{d}$ of SP\#2 (Figs. 4 and 7) in 11:04-11:05 (8 min after the start of ashfall), which indicated the onset of ash aggregate formation. We suggest that the observed recovery of the ash falling rate is similar to the process of secondary thickening, which has been found in tephra deposits generated by Plinian eruptions and attributed to the aggregation of fine ash particles (Carey and Sigurdsson 1982). By combining a time series of ash falling rate and characteristics of GSDs, we have been able to demonstrate that secondary thickening can occur during ashfall generated by Vulcanian eruptions, with the process being triggered by the settling of ash aggregates.

\section{Conclusions}

We quantified the sedimentation process of ash particles during a Vulcanian eruption at Sakurajima volcano, Japan, using GSD analysis and high-speed camera imaging obtained during the eruption sequence at a site $3.5 \mathrm{~km}$ from the vent. We studied two Vulcanian eruptions on 26 March 2016, with the first eruption occurring at 10:44 and the second at 11:26 JST. Ashfall continued from 10:57 to 12:12 at the field site. GSDs of ash samples obtained by high-temporal resolution (1-5 min) sampling exhibited unimodal, bimodal, and trimodal distributions. The grain size of the samples ranged from $6 \mu \mathrm{m}$ to $3 \mathrm{~mm}$. The $M_{d}$ of the main particle size subpopulation (SP\#1), which accounts for $70-99 \%$ of the sampled ash volume, decreased during the course of the ashfall after both the first and second eruptions. This is explained by size-dependent segregation of ash particles from a single constant-height-release source with the effect of advection by horizontal wind. High-speed camera imaging was performed at 10:57, 11:33, and 12:00 and yielded a particle size range of $0.12-2.2 \mathrm{~mm}$ and a falling velocity range of $0.2-7.0 \mathrm{~m} / \mathrm{s}$. The fraction of falling ash with a density of $<1500 \mathrm{~kg} \mathrm{~m}^{-3}$ is interpreted as ash aggregate and decreased over time. The finer subpopulation (SP\#2) is interpreted as fine material that forms ash aggregate and showed an increase in its volume fraction throughout the course of the ashfall. These temporal changes in the density of airborne ash particles and the GSD of ash samples demonstrate that the sedimentation process during a Vulcanian eruption at Sakurajima volcano can be explained by sedimentation of ash particles from the transient volcanic cloud, in which ash aggregation increases over time. The ash falling rate decreased rapidly during the first $8 \mathrm{~min}$ and then increased. This recovery of the ash falling rate was accompanied by an increase in the volume fraction and $S_{d}$ of SP\#2 for sample collected in 11:04-11:05 (8 min after the start of ashfall). We interpret this as showing that secondary thickening can occur during an ashfall generated by a Vulcanian eruption, with the process being triggered by the settling of ash aggregates, which is similar with case in larger-scale Plinian eruptions. The sedimentation process proposed in this study can be applied to models of tephra sedimentation from active volcanoes with frequent short-live eruptions.

\section{Supplementary information}

Supplementary information accompanies this paper at https://doi.org/10. 1186/s40645-019-0316-8.

Additional file 1: Movie S1. High-speed image of airborne ash particles taken in HSC1057. The real length of the movie is 0.028 seconds.

Additional file 2: Movie S2. High-speed image of airborne ash particles taken in HSC1133. The real length of the movie is 0.028 seconds.

Additional file 3: Movie S3. High-speed image of airborne ash particles taken in HSC1200. The real length of the movie is 0.028 seconds.

Additional file 4: Movie S4. The movie was taken in the field site around 11:45-11:46. Diameter of circle patterns in the plastic tray was 1.4 $\mathrm{cm}$.

Additional file 5: Text S1. Density measurement.

\section{Acknowledgements}

We thank R. Kazahaya, N. Geshi, and T. Kozono for advice on the field observations. We are grateful to E. Sato for the series of images of the eruption taken by the JMA time-lapse camera. We acknowledge T. Kanamaru for help with density measurements using the helium pycnometer. We would appreciate two anonymous reviewers and C. J. N. Wilson for their careful readings of the manuscript.

Authors' contributions

TM designed this study, performed all the field and laboratory experiments, analyzed the data of the high-speed camera imaging and grain size analysis, and drafted the manuscript. Yl performed the field observations and the 
grain size analysis and contributed to the drafting of the manuscript. MN contributed to the study design, performed the field observations, and contributed to the drafting of the manuscript. FN performed the grain size analyses and contributed to the drafting of the manuscript. All the authors have read and approved the final manuscript.

\section{Funding}

This study was supported by MEXT/JSPS KAKENHI Grant Number JP26800261

\section{Availability of data and materials}

The dataset used in this study are available at https://doi.org/10.5281/ zenodo 3379289

\section{Competing interests}

The authors declare that they have no competing interests.

\section{Author details}

${ }^{1}$ National Research Institute for Earth Science and Disaster Resilience,

Tennodai 3-1, Tsukuba 305-0006, Japan. ${ }^{2}$ Geological Survey of Japan, AIST, AIST No.7, Higashi 1-1-1, Tsukuba 305-8567, Japan.

\section{Received: 8 October 2019 Accepted: 13 December 2019}

Published online: 09 January 2020

\section{References}

Andronico D, Cioni R (2002) Contrasting styles of Mount Vesuvius activity in the period between the Avellino and Pompeii Plinian eruptions, and some implications for assessment of future hazards. Bull Volcanology 64(6):372-391. https://doi.org/10.1007/s00445-002-0215-4

Bagheri G, Rossi E, Biass S, Bonadonna C (2016) Timing and nature of volcanic particle clusters based on field and numerical investigations. J Volcanology Geothermal Res 327:520-530. https://doi.org/10.1016/j.jvolgeores.2016.09.009

Blott SJ, Pye K (2001) GRADISTAT: a grain size distribution and statistics package for the analysis of unconsolidated sediments. Earth Surface Processes Landforms 26(11):1237-1248. https://doi.org/10.1002/esp.261

Bonadonna C, Genco R, Gouhier M, Pistolesi M, Cioni R, Alfano F, Hoskuldsson A, Ripepe M (2011) Tephra sedimentation during the 2010 Eyjafjallajökull eruption (Iceland) from deposit, radar, and satellite observations. J Geophysical Res Solid Earth 116(B12). https://doi.org/10.1029/2011JB008462

Bonadonna C, Mayberry GC, Calder ES, Sparks RSJ, Choux C, Jackson P, Lejeune AM, Loughlin SC, Norton GE, Rose WI, Ryan G (2002) Tephra fallout in the eruption of Soufrière Hills Volcano, Montserrat. Geological Soc London Memoirs 21(1):483-516. https://doi.org/10.1144/GSL.MEM.2002.021.01.22

Brazier S, Sparks RSJ, Carey SN, Sigurdsson H, Westgate J (1983) Bimodal grain size distribution and secondary thickening in air-fall ash layers. Nature 301(5896):115-119. https://doi.org/10.1038/301115a0

Carey SN, Sigurdsson H (1982) Influence of particle aggregation on deposition of distal tephra from the May 18, 1980, eruption of Mount St. Helens volcano. J Geophysical Res 87(B8):7061-7072. https://doi.org/10.1029/JB087iB08p07061

Chojnicki KN, Clarke AB, Adrian RJ, Phillips JC (2014) The flow structure of jets from transient sources and implications for modeling short-duration explosive volcanic eruptions. Geochemistry Geophysics Geosystems 15(12): 4831-4845. https://doi.org/10.1002/2014gc005471

Chojnicki KN, Clarke AB, Phillips JC, Adrian RJ (2015a) Rise dynamics of unsteady laboratory jets with implications for volcanic plumes. Earth Planetary Sci Lett 412(0):186-196. https://doi.org/10.1016/j.epsl.2014.11.046

Choinicki KN, Clarke AB, Phillips JC, Adrian RJ (2015b) The evolution of volcanic plume morphology in short-lived eruptions. Geology 43(8):707-710. https:// doi.org/10.1130/G36642.1

Clarke AB (2013) Unsteady explosive activity: Vulcanian eruptions. In: Fagents SA, Gregg TKP, Lopes RMC (eds) Modeling volcanic processes: the physics and mathematics of volcanism. Cambridge University Press, England, pp 129-152. https://doi.org/10.1017/CBO9781139021562.007

Costa A, Folch A, Macedonio G (2010) A model for wet aggregation of ash particles in volcanic plumes and clouds: 1. Theoretical formulation. Journal of Geophysical Research 115(B9). https://doi.org/10.1029/2009JB007175

Dellino P, Mele D, Bonasia R, Braia G, La Volpe L, Sulpizio R (2005) The analysis of the influence of pumice shape on its terminal velocity. Geophysical Res Lett 32(21). https://doi.org/10.1029/2005GL023954
Evans JR, Huntoon JE, Rose WI, Varley NR, Stevenson JA (2009) Particle sizes of andesitic ash fallout from vertical eruptions and co-pyroclastic flow clouds, Volcán de Colima, Mexico. Geology 37(10):935-938. https://doi.org/10.1130/ G30208A.1

Eychenne J, Le Pennec JL, Troncoso L, Gouhier M, Nedelec JM (2012) Causes and consequences of bimodal grain-size distribution of tephra fall deposited during the August 2006 Tungurahua eruption (Ecuador). Bull Volcanology 74(1):187-205. https://doi.org/10.1007/s00445-011-0517-5

Folch A (2012) A review of tephra transport and dispersal models: evolution, current status, and future perspectives. J Volcanology Geothermal Res 235: 96-115. https://doi.org/10.1016/j.jvolgeores.2012.05.020

Folk RL, Ward WC (1957) Brazos River bar: a study in the significance of grain size parameters. J Sedimentary Petrology 27(1):3-26. https://doi.org/10.1306/ 74D70646-2B21-11D7-8648000102C1865D

Gilbert J, Lane S, Sparks R, Koyaguchi T (1991) Charge measurements on particle fallout from a volcanic plume. Nature 349(6310):598-600. https://doi.org/10. 1038/349598a0

Hammer J, Cashman K, Hoblitt R, Newman S (1999) Degassing and microlite crystallization during pre-climactic events of the 1991 eruption of Mt. Pinatubo, Philippines. Bull Volcanology 60(5):355-380. https://doi.org/10. $1007 / s 004450050238$

Iguchi M, Tameguri T, Ohta Y, Ueki S, Nakao S (2013) Characteristics of volcanic activity at Sakurajima volcano's Showa crater during the period 2006 to 2011 (Special Section, Sakurajima Special Issue). Bull Volcanological Soc Jpn 58(1): 115-135. https://doi.org/10.18940/kazan.58.1_115

Iguchi M, Yokoo A, Tameguri T (2010) Intensity of volcanic explosions at Showa crater of Sakurajima volcano. Annuals of Disaster Prevention Research Institute of Kyoto University 53:233-240

Imura R (1991) Pyroclastic deposits of Suwanosejima volcano for the last 200 years: a reconstruction of volcanic activity using the volcanic sand formation. J Geological Soc Jpn 97(10):865-868. https://doi.org/10.5575/geosoc.97.865

Imura R (1995) Pyroclastic deposit accumulated by small-scale eruptions. Bull Volcanological Soc Jpn 40(3):119-132. https://doi.org/10.18940/kazan.40.3_119

Iriyama Y, Toramaru A, Yamamoto T (2018) Theory for deducing volcanic activity from size distributions in plinian pyroclastic fall deposits. J Geophysical Res Solid Earth 123(3):2199-2213. https://doi.org/10.1002/2017JB014782

James MR, Lane SJ, Gilbert JS (2003) Density, construction, and drag coefficient of electrostatic volcanic ash aggregates. J Geophysical Res 108(B9). https://doi. org/10.1029/2002JB002011

Kobayashi T, Miki D, Sasaki H, Iguchi M, Yamamoto T, Uto K (2013) Geological Map of Sakurajima Volcano, 2nd Ed. 1: 25,000

Koyaguchi T, Ohno M (2001a) Reconstruction of eruption column dynamics on the basis of grain size of tephra fall deposits: 1. Methods. J Geophysical Res 106(B4):6499-6512. https://doi.org/10.1029/2000JB900426

Koyaguchi T, Ohno M (2001b) Reconstruction of eruption column dynamics on the basis of grain size of tephra fall deposits: 2. Application to the Pinatubo 1991 eruption. J Geophysical Res 106(B4):6513-6533. https://doi.org/10.1029/ 2000JB900427

Kozono T, Iguchi M, Miwa T, Maki M, Maesaka T, Miki D (2019) Characteristics of tephra fall from eruptions at Sakurajima volcano, revealed by optical disdrometer measurements. Bull Volcanology 81(7):41. https://doi.org/10. 1007/s00445-019-1300-2

Miura K, Ban M, Ohba T, Fujinawa A (2012) Sequence of the 1895 eruption of the Zao volcano, Tohoku Japan. J Volcanology Geothermal Res 247:139-157. https://doi.org/10.1016/j.jvolgeores.2012.08.005

Miwa T, Geshi N, Shinohara H (2013) Temporal variation in volcanic ash texture during a Vulcanian eruption at the Sakurajima volcano, Japan. J Volcanology Geothermal Res 260:80-89. https://doi.org/10.1016/j.jvolgeores.2013.05.010

Miyabuchi Y, Hanada D, Niimi H, Kobayashi T (2013) Stratigraphy, grain-size and component characteristics of the 2011 Shinmoedake eruption deposits, Kirishima Volcano, Japan. J Volcanology Geothermal Res 258:31-46. https:// doi.org/10.1016/j.jvolgeores.2013.03.027

Oishi M, Nishiki K, Geshi N, Furukawa R, Ishizuka Y, Oikawa T, Yamamoto T, Nanayama F, Tanaka A, Hirota A, Miwa T (2018) Distribution and mass of tephra-fall deposits from volcanic eruptions of Sakurajima Volcano based on posteruption surveys. Bull Volcanology 80(4):42. https://doi.org/10.1007/ s00445-018-1215-3

Poulidis AP, Takemi T, Iguchi M, Renfrew IA (2017) Orographic effects on the transport and deposition of volcanic ash: a case study of Mount Sakurajima, Japan. J Geophysical Res Atmospheres 122(17):9332-9350. https://doi.org/10. 1002/2017JD026595 
Schumacher R (1994) A reappraisal of Mount St. Helens' ash clusters-depositional model from experimental observation. Bull Volcanology 59(3):253-260. https://doi.org/10.1016/0377-0273(94)90099-X

Sheridan M, Wohletz K, Dehn J (1987) Discrimination of grain-size subpopulations in pyroclastic deposits. Geology 15(4):367-370. https://doi.org/10.1130/00917613(1987)15<367:DOGSIP>2.0.CO;2

Shimbori T (2016) Tephra transport: modeling and forecasting. Bull Volcanological Soc Jpn 61 (2):399-427. https://doi.org/10.18940/kazan.61.2_399

Sparks RSJ, Bursik MI, Carey S, Gilbert J, Glaze L, Sigurdsson H, Woods A (1997) Volcanic plumes. Wiley, New Jersey

Taddeucci J, Scarlato P, Montanaro C, Cimarelli C, Del Bello E, Freda C, Andronico C, Gudmundsson MT, Dingwell DB (2011) Aggregation-dominated ash settling from the Eyjafjallajökull volcanic cloud illuminated by field and laboratory high-speed imaging. Geology 39(9):891-894. https://doi.org/10 1130/G32016.1

Tournigand P-Y, Taddeucci J, Gaudin D, Peña Fernández JJ, Del Bello E, Scarlato P, Kueppers U, Sesterhenn J, Yokoo A (2017) The initial development of transient volcanic plumes as a function of source conditions. J Geophysical Res Solid Earth 122(12):9784-9803. https://doi.org/10.1002/2017JB014907

Walker GPL (1971) Grain-size characteristics of pyroclastic deposits. J Geology 79(6):696-714. https://doi.org/10.1086/627699

Wilson L, Huang T (1979) The influence of shape on the atmospheric settling velocity of volcanic ash particles. Earth Planetary Sci Lett 44(2):311-324. https://doi.org/10.1016/0012-821X(79)90179-1

Wohletz KH, Sheridan MF, Brown WK (1989) Particle size distributions and the sequential fragmentation/transport theory applied to volcanic ash. J Geophysical Res 94(B11):15703-15721. https://doi.org/10.1029/ JB094iB11p15703

Woods AW, Kienle J (1994) The dynamics and thermodynamics of volcanic clouds: theory and observations from the April 15 and April 21, 1990 eruptions of Redoubt Volcano, Alaska. J Volcanology Geothermal Res 62(1-4): 273-299. https://doi.org/10.1016/0377-0273(94)90037-X

\section{Publisher's Note}

Springer Nature remains neutral with regard to jurisdictional claims in published maps and institutional affiliations.

\section{Submit your manuscript to a SpringerOpen ${ }^{\circ}$ journal and benefit from:}

- Convenient online submission

- Rigorous peer review

- Open access: articles freely available online

High visibility within the field

- Retaining the copyright to your article

Submit your next manuscript at $\boldsymbol{\nabla}$ springeropen.com 